\title{
The Speaking Persona: Ancient Commentators on Choral Performance
}

\author{
Francesca Schironi*
}

One influential modern approach to genre in Greek lyric poetry is to focus on performance. ${ }^{1}$ On the other hand, while distinguishing lyric poetry either by meter or by eide (i.e., content, purpose, and occasion), ${ }^{2}$ ancient commentators seem to have had much less interest in purely performative questions. ${ }^{3}$ For them, genre mostly was an issue of "speaking persona," as most clearly outlined by Proclus in his Prolegomena to Hesiod:

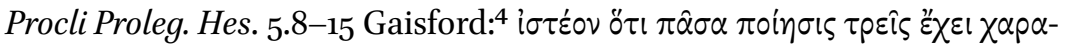

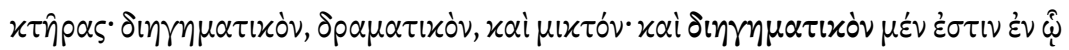

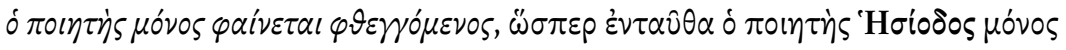

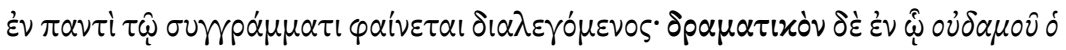

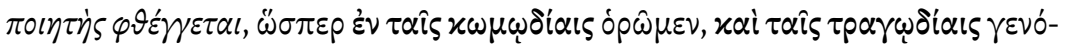

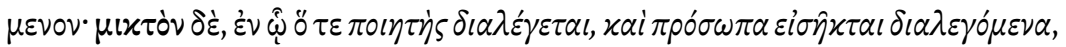

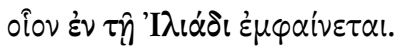

It is important to note that poetry as a whole is of three types: narrative, dramatic, and mixed. Narrative is [the type] in which only the poet appears to be speaking, as here the poet Hesiod alone appears to be speaking throughout the entire poem. Dramatic [is the type] in which the poet

* I would like to thank Giambattista D'Alessio, Meg Foster, Leslie Kurke, Monica Negri, and Naomi Weiss for their help and suggestions.

1 See, for example, Calame 1974, 1977 [1997a/20o1, in English]; Gentili 1984 [1988, in English]; Lardinois 1994, 1996; Nagy 1990, 1994-1995, 1996.

2 See Färber 1936 (which is still the most complete collection of ancient sources on lyric poetry); Irigoin 1952: 31-75; Harvey 1955; Negri 2004.

3 As Rutherford 2001: 107 rightly observes, "most cases of eidographic indeterminacy arose because Hellenistic classifiers tended to neglect the performance scenario of songs in favour of formal features, and to the extent that they were concerned with performance, they may sometimes have misinterpreted it."

4 Gaisford 1823: 5 . 
never speaks, as we see to be the case in comedies and tragedies; mixed [is the type] in which the poet speaks and introduces characters speaking, as is clear in the Iliad. $^{5}$

The division among narrative, dramatic, and mixed genres is fairly common in antiquity and derives from Plato, who famously in the Republic (392d-394d) distinguishes between dramatic imitation (tragedy and comedy), narrative (dithyrambs), and a mix between dramatic and narrative (epic poetry). ${ }^{6}$ Aristotle, too, seems to have the same definition in mind when (Poet. 1448a2O-24) he says that it is possible to present things by narrating and becoming another person, as Homer does (i.e., Plato's mixed type) or by remaining the same (i.e., Plato's narrative), or by representing people who act (i.e., Plato's dramatic). ${ }^{7}$ Aside from tragedy and comedy, which are easy to label as "dramatic" ( $\delta \rho \alpha \mu \alpha-$ $\tau(x o ́ v)$, this conceptualization of literary genres gives unexpected results when compared to our theory of genres. Whereas we label dithyramb and epinician poetry as "choral lyric" and consider Homer and Hesiod as belonging to "epic" because we look at the performative aspects of each genre, ancient exegetes saw these texts mostly from the point of view of the speaking personaand this changed everything. In this perspective, Hesiod is now coupled with dithyramb as examples of "narrative" poetry ( $\delta \eta \eta \eta \mu \alpha \tau i x o ́ v)$ because the poet is the only speaking voice. Homer, on the other hand, belongs to the "mixed" genre ( $\left.\mu \varkappa \tau \tau^{\prime}\right)$ because he alternates narrative parts, where he is the speaking persona, with dramatic ones, where he introduces his characters, who speak directly within the text.

Starting from these premises, in what follows I will examine the attitudes towards choral performance in exegetical literature, and especially in the scholia to Pindar, to see whether these sources can give us a clue as to which genre Pindar's poems belonged and why. This analysis will also show that while Hel-

5 All translations are mine.

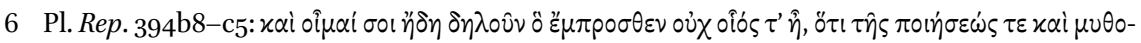

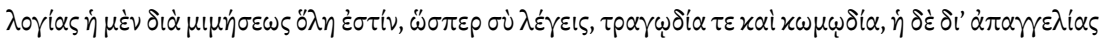

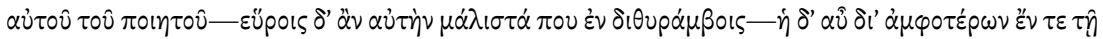

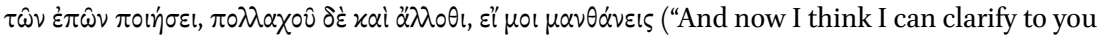
what I was unable to before, that one type of poetry and story-telling is completely through imitation — as you say, tragedy and comedy; another happens through the narrative of the poet himself-you may find it especially in dithyrambs; and one happens through both [i.e., narrative and imitation], and [this happens] in epic poetry and in many other genres, if you understand me").

7 On this classification, see Färber 1936: 3-7; Haslam 1972: 20-24; Nünlist 2009: 94-99 (with further bibliography). 
lenistic and later scholars might not have read lyric poetry with a specific interest in performance per se (rather their focus was indeed on explanations of words, myths, and characters referred to in the lyric texts), they did take an interest in the chorus. Yet their attitude towards choral performance was very different from ours and was determined by a different conceptualization of poetic genres, in which the "speaking persona" was more important than the performative aspects of each type of text.

\section{The Chorus Speaks to and Is Addressed by the Poet}

Dances and choral performances were common in the Hellenistic period and many contemporary inscriptions testify to their popularity. ${ }^{8}$ Thus, at least from their own experience, the Alexandrian scholars were well acquainted with the fact that lyric poetry was sung and danced. ${ }^{9}$ The question is whether they bothered to discuss performative aspects beyond questions of prosody or meter, which were important simply for editing lyric poems. ${ }^{10}$ Music and dancing are a different matter because, even if related to the rhythm of the text, they are external to it from an editorial or exegetical point of view.

The scholia to Pindar offer some interesting evidence when it comes to the chorus' actions and performative acts. In what follows I will focus on this corpus $^{11}$ and other evidence from the fourth century вСЕ to the Byzantine period to examine how ancient commentators looked at the choral performance of lyric poetry. ${ }^{12}$

8 As shown by Chaniotis 2009 in his survey of the evidence available (inscriptions, papyri, and ancient authors); cf. also Prauscello 2006: 104-116.

9 See Pretagostini 2009, who surveys the evidence for musical and choral performances in Callimachus and Theocritus. On the idea of the "chorus" in Greek authors from Plato to Dionysius of Halicarnassus, see Peponi 2013c.

10 On Aristophanes' editorial criteria for Pindar's and Bacchylides' poems, see Irigoin 1952: 35-48 and Negri 2004: 152-176.

11 I will not consider fragments of commentaries on papyrus. In preparing this article, however, I surveyed all the marginalia to lyric poetry collected by McNamee 2007 as well as several fragments of papyrus hypomnemata on the main lyric poets, and did not find any specific notes on performance (with the exception of minor notations which I quote below in nn. 16 and 51 ). As for the Pindar scholia, I have disregarded notes discussing prosody and meter as well as those discussing the "external" realities of the Pindaric odes, such as the specific festival or occasion, because the former have more to do with the editorial activity and the latter with the historical context of the ode rather than with its performance. Some scholia discussing cultic contexts connected with Pindaric odes have been recently studied by Ferrari 2012.

I follow the edition and line numeration of Snell-Maehler for Pindar's text. However, the 
Most often the scholia mention the chorus when they need to explain who is speaking in an ode-which suggests that ancient scholars included the chorus among the "speaking personae" in a lyric poem. Thus a $\lambda$ óyos can be attributed

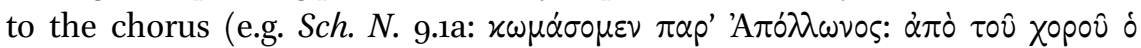
$\lambda$ óros). ${ }^{13}$ Aside from other cases of first-person statements, ${ }^{14}$ addresses or sentences within the poem are also attributed to the chorus. ${ }^{15}$

Yet the chorus is not the only speaker in Pindar's odes. So, for example, commentators are sometimes in doubt whether to attribute the words to the poet or to the chorus. ${ }^{16}$ In other instances, they note exchanges between the chorus and some other speaking persona, most often the poet. This especially occurs when an imperative is used. When this occurs, scholiasts usually understand it as addressed by the poet to himself or to the chorus, as happens, for instance, in a series of scholia to Olympian 9 all discussing second-person singular impera-

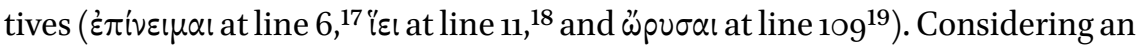
imperative singular as addressed to the multitude of the chorus members was not a problem. Indeed, according to Aristarchus, this was typical of Pindar: ${ }^{20}$

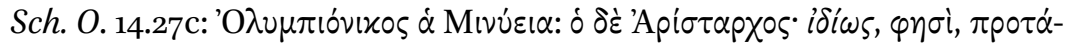

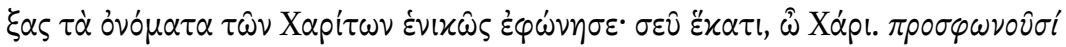

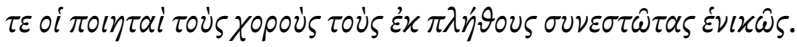

scholia edited by Drachmann 1903-1927 follow the previous numeration (which supposedly goes back to Aristophanes of Byzantium), so there is a discrepancy between the line references in the scholia and the lines of Pindar.

$13 x \hat{\omega} \mu \circ \varsigma$, "revel," and derivatives are often "translated" in the scholia with "chorus" and

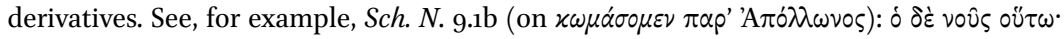

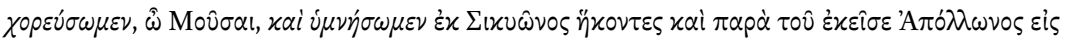

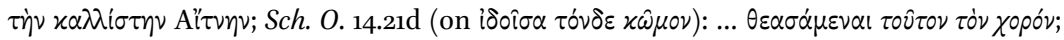

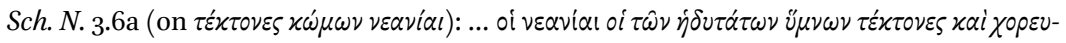
$\tau \alpha i$. There are, however, exceptions: see below, n. 23 .

14 E.g., Sch. P. 9.172 (where the commentator takes عîंov as first person singular rather than third person plural, as correct); Sch. I. 7.51a.

15 E.g., Sch. O. 4.7h; Sch. O. 8.66; Sch. P. 8.140c (briefly discussed below).

16 E.g., Sch. P. 5.96a; Sch. P. 6.1a (but see Sch. P. 6.1e). In Pae. 8 in POxy. 5.841, two scholia discuss whether it is the poet or the chorus speaking in the incipit; cf. D'Alessio 1991: 101; Rutherford 2001: 212, 216; McNamee 2007: 321.

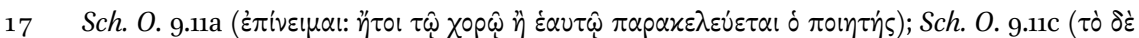

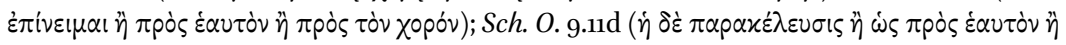

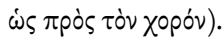

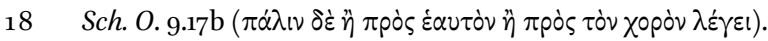

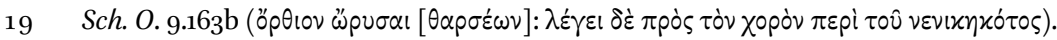

20 On Aristarchus' Pindaric studies, see Horn 1883 and Irigoin 1952: 51-56. 
"[For I have come singing of Asopichus in Lydian mode with my art, because] the Minyan land is victorious at Olympia [thanks to you ( $\sigma \varepsilon \hat{v}$

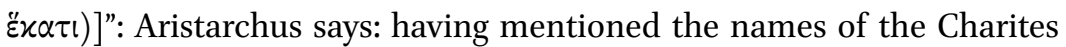
[above] (i.e., at lines 13-15) in his typical manner [Pindar] has [now] addressed them in the singular: "thanks to you, Charis." And the poets address the choruses, which consist of a multitude of people, using the singular..$^{21}$

When, however, the imperative is followed by a vocative singular and also a reference to "companions," then the guess is that Pindar addresses the chorodidaskalos. This, for example, is the case with Olympian 6, where after a long passage with a speaking I (82-87), we read "Now, Aeneas, exhort your companions first to sing Hera the Maiden" (87-88). The scholiast concludes that Aeneas was the chorodidaskalos "whom he [i.e., Pindar] used because he himself had a thin voice and was not able to speak at length to the chorus by himself in public" (Sch. O. 6.148a). ${ }^{22}$

Finally, another speaking persona appears in the scholia: the laudandus, who can sometimes speak directly in the poem. For example, when in Pythian 9 we read (88-89): "I will celebrate them (i.e., Heracles and Iphicles) with a revel, as I have experienced a good thing, in accomplishment of my prayer," the ancient commentator concludes that "the words are addressed to Heracles and Iphi-

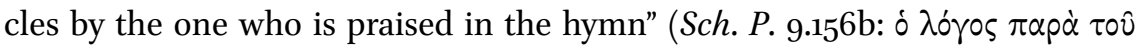

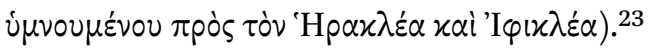

As is clear, most of these attributions are deduced from the text itself on the basis of common sense or using factual information connected with details concerning the poet, the chorus, or the laudandus.

This attitude of deducing speakers on the basis of textual clues emerges most clearly when we look at Pythian 8, whose scholia have been studied by many

21 Yet, even when the plural imperative is used, ancient commentators suggest that Pindar is giving commands to the chorus or deities in the plural, as for example in Sch. O. 10.1a

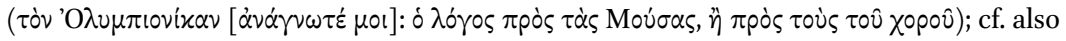
Sch. O. 10.1d, h, i.

22 Cf. also Sch. O. 6.149a. But when later on (92-93) the singular imperative is not followed by

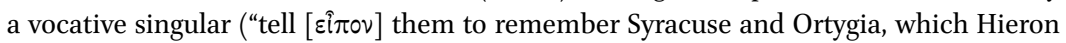
rules with a pure scepter"), Aristarchus concluded that the poet is now addressing the chorus as a whole (Sch. O. 6.158b).

23 Even if the first-person verb here is $\varkappa \omega \mu \alpha \dot{\sigma} \sigma \mu \alpha$, "I will celebrate with a revel," the commentator concludes that the speaking persona is not the chorus, as is usual (see n. 13 above). This is so presumably because the reference to a recent success clearly points to the victor. 
scholars. ${ }^{24}$ According to the scholia, the first part of the ode up to line 55 is considered to be sung by Pindar (with some direct words by Amphiaraus at lines 44-55). ${ }^{25}$ Then (55-66) the chorus speaks (perhaps in the victor's persona), then Pindar again (67-69), and finally the chorus in its own persona (70-100). Edwin Floyd, who studied this case, thought that the ancients were correct in this reconstruction and suggested that they had a score to look at. ${ }^{26} \mathrm{I}$ do not think that we necessarily need to assume that they had a score to come up with this line attribution. On closer analysis, we see that all the scholia indicating a speaker do so because there is a reference in the text that suggests that speaker. References to a "lyre," the "gentle voice" (31), or the "art" (34) suggest that Pindar is the speaker (Sch. P. 8.40a, Sch. P. 8.4ob, Sch. P. 8.43a on line 31; and Sch. P. 8.46b on line 34). The claim that the hero Alcmeon is a neighbor (57-58) excludes, in these commentators' minds, Pindar as the speaking voice. Two possibilities are thus suggested: either the chorus speaks impersonating the victor, who lived next to a heroon of Alcmeon (Sch.P. 8.78a), or the chorus is simply speaking in its own persona because the chorus members, just like Aristomenes, are from Aegina (Sch. P. 8.83a) — so Alcmeon can be both neighbor and guardian of either Aristomenes or the chorus members. ${ }^{27}$ Then, the "harmony" at line 68 suggests Pindar again (Sch. P. 8.95a). Finally, the mention of a komos (70) and the fact that Aegina is called "mother" (98) suggest that this is the chorus speaking (Sch. P. 8.99a on line 70 and Sch.P. 8.140c on line 98), since Pindar is not from Aegina and (presumably) does not revel. ${ }^{28}$ All the exchanges are thus deduced from the text and some special keywords connected with each one of the three characters "onstage": the poet, the chorus, and the victor.

24 Floyd 1965; Lefkowitz 1975: 179-184; and Meijering 1987: 121-122 (who reads them in a slightly different way).

25 Cf. Sch. P. 8.1b and Sch. P. 8.10a.

26 In particular Floyd (194) suggested the following division: $1-55$ sung by the coryphaeus; $55^{-}$ 66 sung by the chorus (in persona victoris); 67-69 sung by the coryphaeus; 70-100 sung by the chorus (in propria persona). In other words, the coryphaeus would sing alone when impersonating Pindar.

27 Unless, as Sch. P. 8.78b suggests, the neighbor is Amphiaraus, who died at Thebes, and thus can be considered as Pindar's neighbor - in this case, Pindar would be speaking; cf. Lefkowitz 1975: 180; Hubbard 1993; Pfeijffer 1999b: 540-545.

28 In fact, Aristomenes could also utter these words, since he is from Aegina too. This is probably why Sch. P. 8.140c suggests the chorus as a hypothesis ( 


\section{The Chorus, Pindar, and Other Characters}

As our survey has shown, ancient scholars seem above all to see the chorus as mainly a speaking persona in an ode, alternating lines with the poet and sometimes with the victor himself. This idea was used to explain many first-person statements, personal references, and imperatives in the text. The ambiguous first-person statements in Pindar are still hotly debated among modern scholars, ${ }^{29}$ so it is not surprising that the ancients, too, found it problematic to deal with the Pindaric speaking voice. Yet their way of approaching the "speaking I" in lyric poetry seems to be profoundly different from ours. In this regard, a scholium to Nemean 7 gives some interesting clues. The explanation here is again triggered by a reference in the text, when Aegina is defined as "my [illustrious] native land" (85: $\dot{\varepsilon} \mu \hat{\alpha} \ldots \pi \dot{\alpha} \tau \rho \alpha)$ :

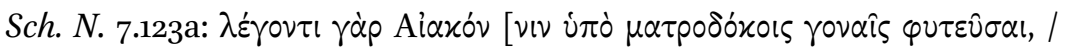

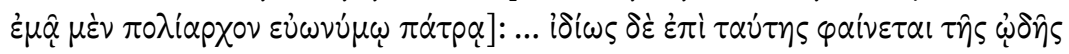

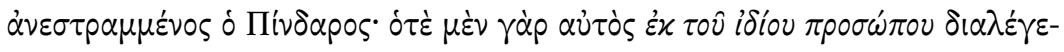

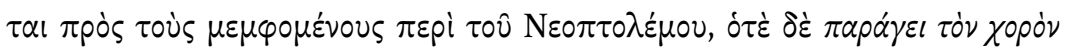

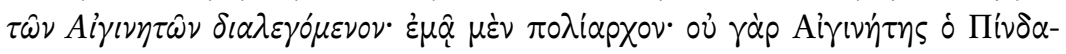
pos.

"For they say that by the seeds received by the mother, he generated Aeacus, prince in my illustrious land": ... Pindar seems to have used an alternation [of speakers] in this song, as is typical of him. For sometimes in his own persona he himself addresses those who censure Neoptolemus, sometimes, on the other hand, he introduces the chorus of the Aeginetans talking [as happens here]: "prince in my [illustrious land]." For Pindar is not from Aegina.

Since Pindar is not from Aegina, the commentator deduces that this is the chorus speaking, while elsewhere in the poem Pindar has spoken in his own persona. While this is the usual problem involving a "speaking I," what is interesting in this note is the use of a specific formula of ancient scholarship on

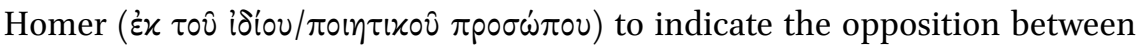
Homer and his characters. For example, a very close parallel to this phrasing can be found in the following scholium in which Aristarchus discusses the use of trumpets in a Homeric simile:

29 Among the most famous and recent studies, see Lefkowitz 1991; D'Alessio 1994; Currie 2013. 


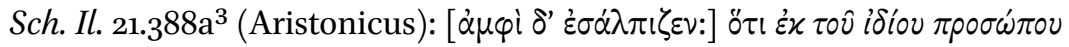

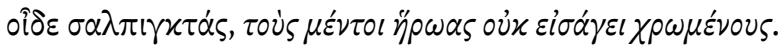

["And [great heaven] trumpeted around":] because speaking in his own persona he knows trumpets, but he does not introduce heroes as using them.

Aristarchus correctly notes that the trumpet is unknown to the Homeric heroes, and so Homer never introduces characters using it; however, a metaphorical use of the derived verb $\sigma \alpha \lambda \pi i \zeta \varepsilon i v$ in the narrative shows that Homer knew this instrument. ${ }^{30}$ While this is not a question of deciding who is speaking, the theoretical background is the same: Aristarchus, just like the anonymous commentator in $S c h . N .7 .123$ a, sees the poet either speaking in his own

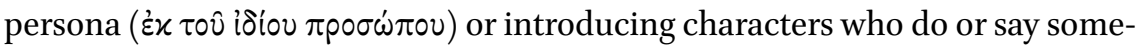

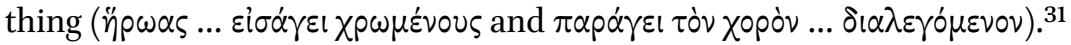

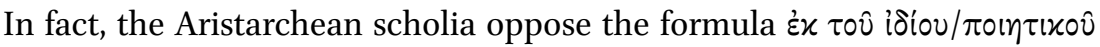
$\pi \rho \circ \sigma \dot{\omega} \pi \circ v$ (when the poet speaks in in own persona) to $\dot{\xi} \xi \dot{\eta} \rho \omega \ddot{x}$. (when his characters, i.e., the Homeric heroes, are speaking). For instance, Aristarchus explains that Ephyra is a byname for Corinth and is the name used by the characters. On the other hand, when Homer speaks in his own persona (i.e., in the narrative), he calls it Corinth:

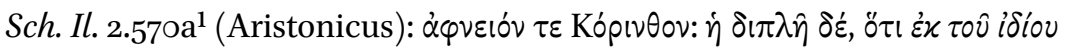

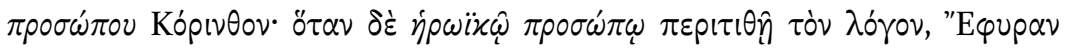

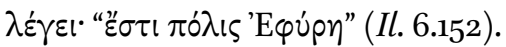

"And wealthy Corinth": the diple 32 [is placed here] because [he says] "Corinth" speaking in his own persona; when he makes his heroic characters speak, he says "Ephyra": "there is a city called Ephyra" (Il.6.152). ${ }^{33}$

30 See Schironi 2018: 334 .

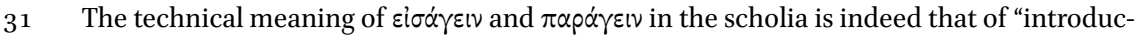
ing a character" in the sense of "putting him/her onstage." See Meijering 1987: 127, who rightly notes that "Greek literary theory does not draw a very sharp line between presenting a scene literally on the stage and presenting a narrative scene to the mind's eye." In this article I offer a possible answer for why this is so.

32 On the diple, a critical sign used by Aristarchus, see Schironi 2018: 49-52.

33 See also Sch. Il. 6.152b (Aristonicus) and Sch. Il. 13.301b (Aristonicus); cf. Schironi 2018: 298 and 511 . 
Since in victory odes "real" heroes normally do not speak, in the Pindar scholia we find a variant of these formulas, $\pi \alpha p \alpha \dot{\alpha} \tau o \hat{v} v i x \eta \varphi o ́ p o v$, to indicate that the laudandus is the speaking persona. This happens in the scholia discussing $I .7 \cdot 39-42$, lines which contain two first-person statements. The first one (39: "I will sing [a $\dot{\varepsilon} i_{\sigma o \mu \alpha l]}$ adorning the hair with a wreath; may the envy of the immortals not disturb us") obviously pointed to the poet, who "sings," as the speaking voice (Sch. I. 7.53a). The question, on the other hand, was how to interpret the following statement (40-42): "by pursuing the pleasure that

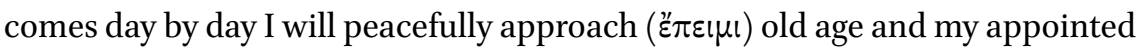
time." For Aristarchus, these words, too, were spoken by the poet (Sch. I. 7.55a), but another anonymous commentator suggested adding a period at the end of line 39 , so as to consider lines $40-42$ as spoken by the victor:

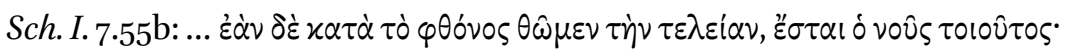

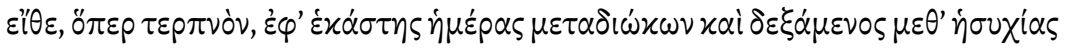

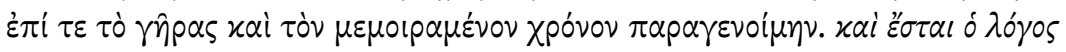

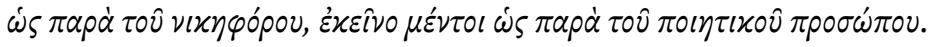

... However, if we put the full stop after "envy," this will be the meaning: "I wish that pursuing what is pleasurable every single day and receiving it in peace, I would reach old age and my appointed time." And the words will be as spoken by the victor; on the other hand, that solution [i.e., Aristarchus' solution] is [that the words are] as spoken by the persona of the poet. ${ }^{34}$

Needless to say, just as in the cases analyzed above, both solutions are derived from the text; in fact, while the first action ("I will sing") clearly points to the poet, the second one ("I will approach old age, etc.") could fit both the poet (as Aristarchus suggests) and the laudandus (as the anonymous commentator prefers). Yet this scholium is interesting because it uses labels common in Homeric criticism, here adapting them to Pindar's specific context (where the victor is also a speaker). In addition, it proves that Aristarchus, who conceptualized Homer's speaking voices in that way, also took an interest in the question of who was speaking in Pindar, so here the connection between Homeric and Pindaric exegesis becomes clear.

Indeed the same formulas are used in the scholia to Pindar even in the absence of a first-person statement, as in the Homeric examples just discussed:

34 For other cases of the formula (or variations of it) to indicate the victor as the speaking

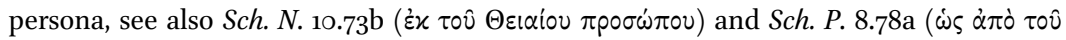

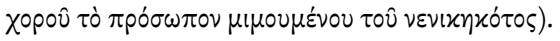




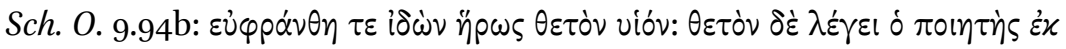

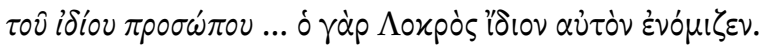

"And the hero rejoiced at seeing his adopted son": the poet says "adopted" speaking in his own persona ... for Locrus considered the baby as his own.

The hero mentioned here is Locrus; Zeus impregnated the daughter of Opous of Elis and gave her as a bride to Locrus. Hence the baby is an "adopted" son for Locrus. Yet this is valid only from the point of view of an omniscient narrator, that is, Pindar, and not for Locrus, who considered the baby to be his own son; so in this line - the commentator concludes-it is Pindar speaking. ${ }^{35}$

The use of these formulas typical of Homeric scholarship with reference to Pindar's poems suggests that the exchanges between the poet, the chorus, and the laudandus are not seen so much from a performative point of view, but instead are viewed like the exchanges in speaking-personae in the Homeric poems. This is especially clear because, just as with the Homeric lines, in Pindar, too, these "line attributions" are not limited to first-person statements but even concern what we would consider "impersonal" statements within the narrative parts. In commenting on both Homer and Pindar, scholars considered certain words or expressions (e.g. "trumpets," "Ephyra," or "adopted") suitable only to a certain category of speakers, and this is how they attributed the lines. If this is true, that is, if the question of who was speaking in the lyric text was conceived by the ancient grammarians as a question of "characters," we can look at all these notes discussing changes of speakers from a different perspective.

\section{Change of Speakers and Ancient Editions}

Normally (and not surprisingly) ancient discussions about changes of speakers are frequent in dramatic texts. ${ }^{36}$ Similarly, papyri of dramatic texts often signal changes of speakers either by paragraphoi or by characters' names, as in a papyrus of Euripides' Hypsipyle (POxy. 6.852, second-third centuries CE). In the case of actors' texts there are letters denoting actors' roles. POxy. 27.2458 (third century $\mathrm{CE}$ ), for example, contains a fragment from Euripides' Cresphontes with the stage indications $A$ and $\Gamma$ for the two actors. ${ }^{37}$

35 For other cases of the formula घंx/àं O. 6.88c; Sch. O. 13.10oc; Sch. P. 4.67b.

36 Cf. Nünlist 2009: 338-343.

37 Cf. Gammacurta 2006: 95-110. See also POxy. 3.413; P.Hibeh 2.180; PSI 10.1176; P.Ryl. 3.484; 
As for lyric poetry, I have analyzed elsewhere cases in which ancient editors and commentators indicated the change of speakers. ${ }^{38}$ The most interesting example among those I discussed was the Louvre papyrus of Alcman (first century CE), which has three marginal notes as well as paragraphoi at lines $35^{-}$ 63 of the Partheneion that signal a semi-choral exchange between the girls on

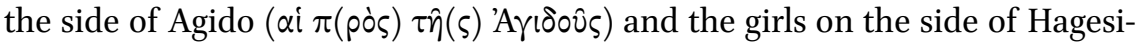

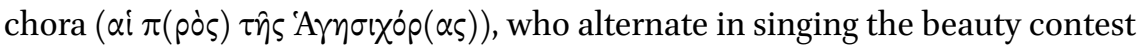
between Agido and Hagesichora. ${ }^{39}$ The commentator does not speak of "semichorus A" and "semi-chorus B," which would suggest a "performance" text, as in the papyri with actor's notes. Rather, the Alcman papyrus uses the names of the "characters" in the poem, Agido and Hagesichora, and this seems to point more to a "reader's text," just as in dramatic papyri where the characters' names, and not the actors' sigla, are marked. The scribe of the Alcman papyrus comments upon a written text, even if he probably knew that it was originally performed.

In fact, the interest in speakers is not limited to performative texts. Speaker indications appear also in some Homeric papyri. ${ }^{40}$ These can signal changes of speakers simply with paragraphoi. For example, P.Berol. inv. 7807 (second-third centuries CE) has a paragraphos to mark the beginning of Achilles' famous speech in Iliad 9 (308). P.Mich. inv. 2810 (second century CE), on the other hand, marks every change of speaker in Iliad 1 with slanting paragraphoi. In particular, here also changes of addressees within a speech are marked, as at line 334, Achilles first addresses the heralds and at line 337 he then speaks to Patroclus, both marked in the manuscript (fig. 4.1).

In some Homeric papyri, the scribes even added the names of the speakers in the margin. For example, P.Strasb. gr. inv. 31-32 verso, a fragment of a roll dating to the early third century $\mathrm{CE}$, has the names of the speakers and the addressees throughout Iliad $1{ }^{41}$ Most interestingly, here the scribe has also marked when Homer, "the poet," is speaking. For example in column v, lines 1-20, covering Iliad 1.317-336, we read (see also fig. 4.2):42

P.Berol. inv. 13876; P.Berol. inv. 21119; P.Varsov. 2; P.Lit.Lond. 97, studied by Gammacurta 2006: 7-94.

$38 \quad$ Schironi 2016.

39 See discussion in Schironi 2016: 33-38. For an image of the papyrus, see Römer 2013, tab. I-VII.

40 They have been recently studied by Azzarello 2008.

41 Edited by Schwartz 1954: 45-62.

42 I reproduce the text of the papyrus as edited by Schwartz 1954: 49, but have added diacritics and readings aids; I have also eliminated the many itacistic errors present in the papyrus. On the other hand, I have added the three paragraphoi which the scribe used 


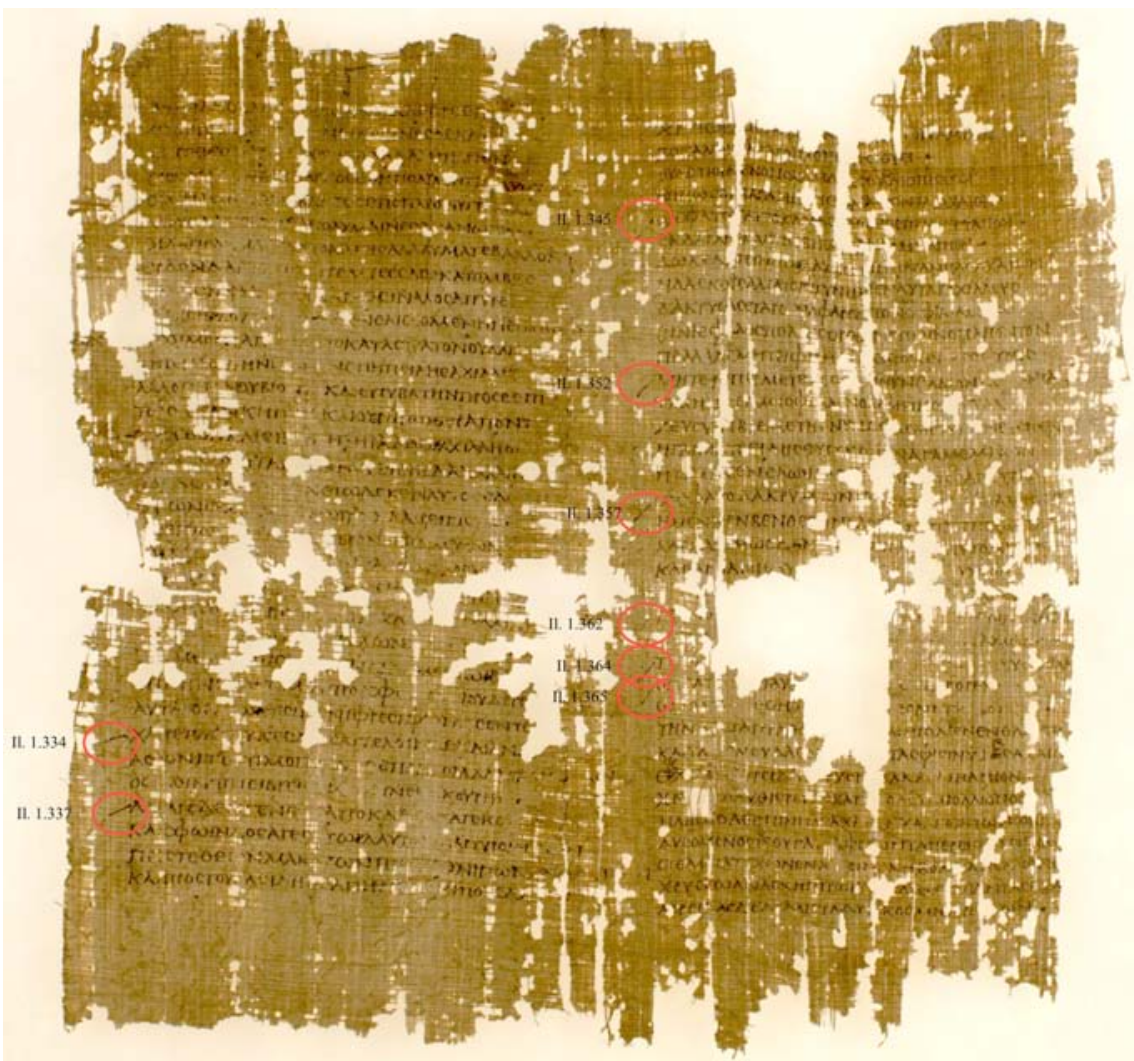

FIGURE 4.1 P.Mich. inv. 2810 (second century CE), fr. A, with Il. 1.308-375 (cols. X-XI) IMAGE COURTESY OF THE UNIVERSITY OF MICHIGAN PAPYROLOGY COLLECTION

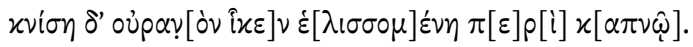

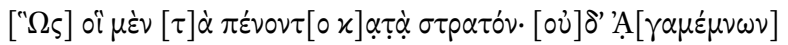

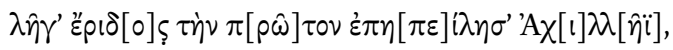

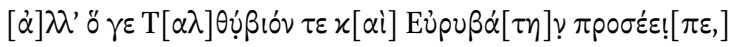

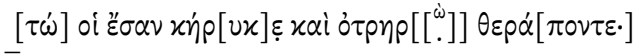

to mark the change of speakers (in addition to the names in the margin); Schwartz transcribed only one of them (the one between lines 325 and 326), but the digital image of the papyrus clearly shows that paragraphoi are also present between lines 321 and 322 and lines 333 and 334. 
325

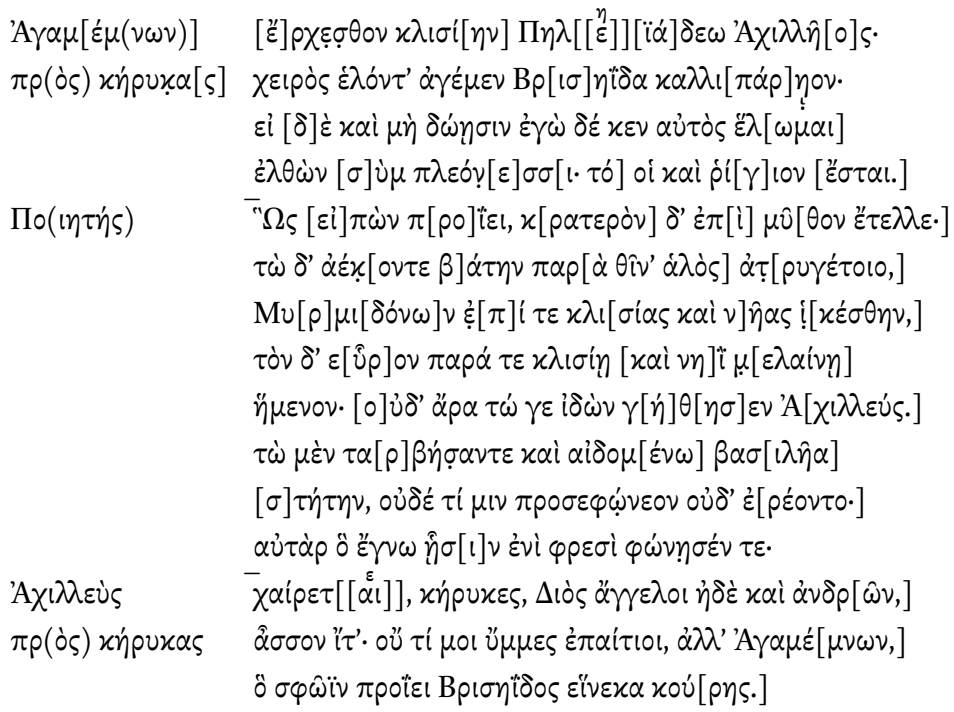

And the smell reached the heaven, rolling with the smoke.

In this way they were busy in the camp. But Agamemnon

did not stop from the strife he started when he first threatened Achilles, but he spoke to Talthybius and Eurybates who were his two heralds and quick servants:

Agamemnon "Go to the hut of Achilles, son of Peleus.

to the heralds Taking fair-cheeked Briseis by the hand, lead her away.

If he does not give her, I myself will take her, coming with more men. This will be even worse for him."

Poet After he said so, he sent them away and gave them a stern order. The two men unwillingly went along the shore of the barren sea and arrived to the huts and ships of the Myrmidons.

They found him sitting near his hut and black ship; and Achilles did not rejoice upon seeing them.

They, feeling fear and respect for the lord, stood still and did not address him nor did they ask anything. But he realized this in his heart and spoke to them:

Achilles "Greetings, heralds, messengers of Zeus and of men, to the heralds Come closer. You are not guilty towards me, but Agamemnon, Who sent you two for the girl, Briseis."

In this ancient edition of the Iliad, Homer is equated with his characters, which is exactly what we have seen for Pindar and the chorus. The type of phrasing

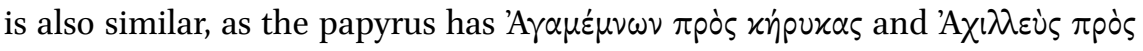




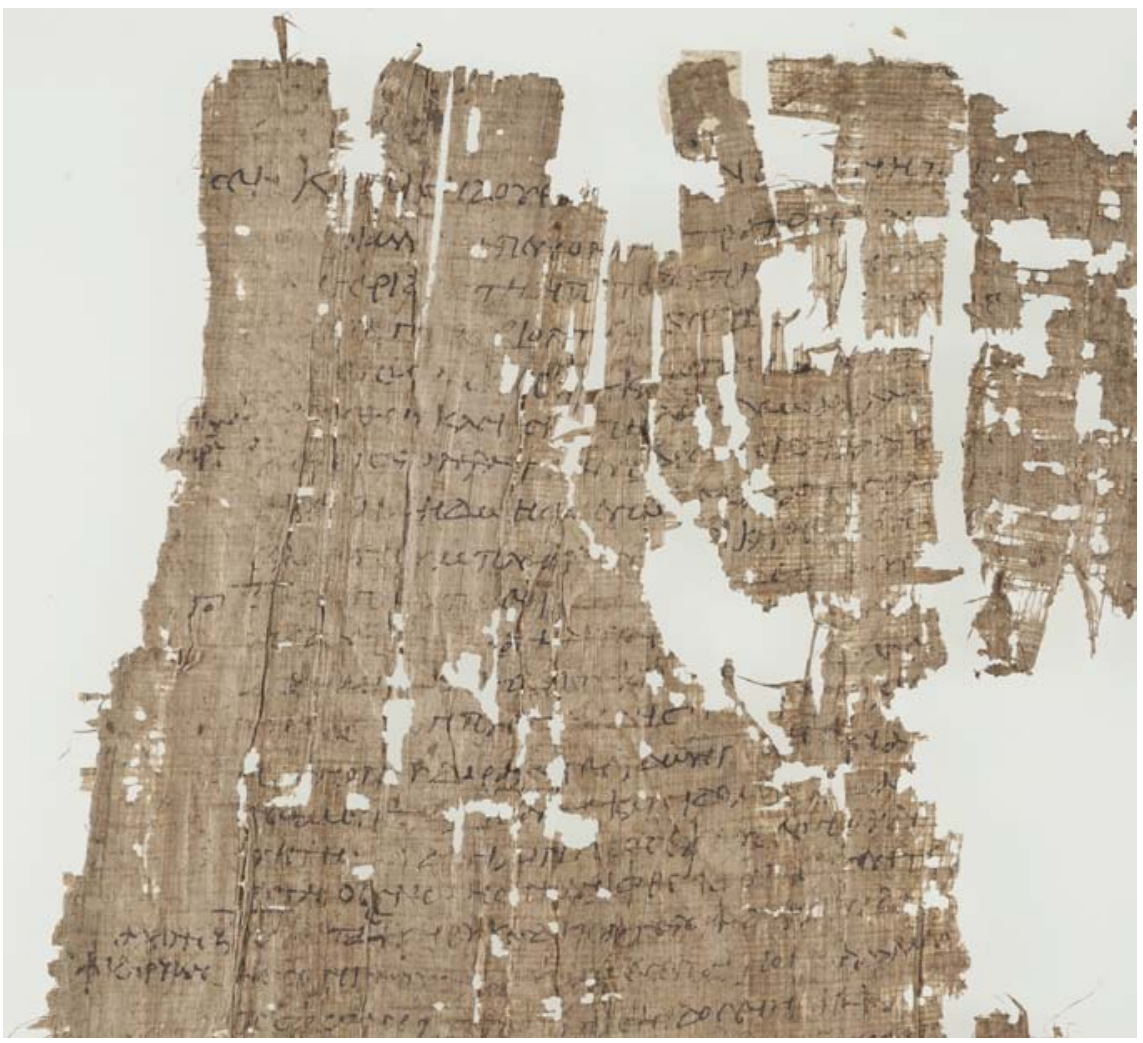

FIGURE 4.2 P.Strasb. gr. inv. 31-32 verso (early third century CE), v, lines 1-20 (Il. 1.317-336).

IMAGE COURTESY OF BNU STRASBOURG

xńpuxas, phrases which parallel what we read in the Pindar scholia when they

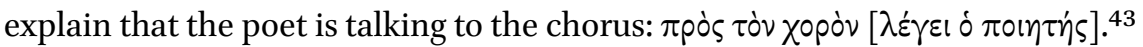
The famous Bankes Homer (P.Lit.Lond. 28, second century CE), a luxury edition of Iliad 24, works in almost the same way but has only the name of the speakers, not that of the addressees. Here, too, different speakers are named: Cassandra, Priam, Andromache, Hecuba, and again the poet. ${ }^{44}$

With Homer it is quite easy to find out who is speaking because the omniscient narrator introduces speakers. So in theory there is no need to indicate changes of speakers in an edition, unless the text itself is conceived as an

43 See above nn. 17, 18 and 19.

44 In POxy. 2.223 (third century CE), containing Iliad 5, at cols. ix-xiii (Il. 5.204-290) the "poet" is listed together with other speaking characters: "Pandarus," "Aeneas," "Sthenelus to Diomedes," "Diomedes." The rest of the papyrus often has the left margin missing, so other indications might have been lost. 
exchange of speaking roles from the start, where the poet intervenes among characters. At the level of exegesis, on the other hand, since with Homer usually there is no problem in identifying characters, this is not an urgent problem and so there are not many scholia discussing who is speaking. ${ }^{45}$ In the case of drama and lyric poetry, on the other hand, the identification of speakers is a problem because there is no external narrator to introduce them, and so sometimes the exact attribution of lines among characters may be unclear (a problem which modern editors of tragedy and comedy still face). The ancients tried to solve these uncertainties by using clues from the text itself. For instance, the ancient scholar of the Alcman papyrus could certainly have derived the notion of the two semi-choruses from just reading the poem, especially for the lines containing the "beauty contest" - even though Pollux's Onomasticon (4.107, p. 233.4-9 Bethe) confirms the presence of semi-choruses in Sparta, and Sosibius, the Hellenistic authority for ancient Sparta, says that gymnopaidiai were performed by triple choruses, one of boys, one of men, and one of old men, and that they also sang odes by Alcman (Ath. 15.678b-c).$^{46}$ Similarly, our analysis of the Pindar scholia has shown that all notes discussing the chorus' words are derived from the text itself. This, of course, does not mean that ancient scholars did not know how lyric poetry was performed originally, that is, with a chorus that danced and spoke all the words of the poem. They were also aware that Pindar was most likely absent from the scene and that the victor, even when present, was simply sitting and enjoying the performance, without uttering a word. Yet they conceived of both Pindar and the victor as active speaking personae, as "characters," who did not actually need to perform the ode to be part of its text, just like the chorus. The notes in the Alcman papyrus as well as those on Pindar do not betray any interest in performance, but rather an interest in clarifying the text seen as an exchange among speaking personae; the aim is to give each line to the proper character using the text itself as evidence.

\section{Beyond Speaking, What Does the Chorus Do?}

As we have seen, in the Pindar scholia the chorus is an important speaking persona. Yet, from a performative point of view, a chorus should be also

45 Those scholia discussing who is speaking often do so when direct speeches are not introduced by a verb of saying; see Aristarchus in Sch. Il. 4.303a; 16.203a; 23.855a. On the other hand, the Homeric scholia very often consider whether Homeric speeches fit the characters who say them; cf. Schironi 2018: 429-433, 435-437, 456-461.

See Schironi 2016: 46-49. 
(or mostly?) dancing. The way ancient scholiasts discuss choral dancing or physical movements is, however, quite disappointing if we are looking for insights into ancient choral performance. Where scholia talk about movements of the chorus it is because some word for movement occurs in the text. ${ }^{47}$ Verbs of movement suggest to the ancient scholars' mind that someone is engaged in physical movement, whether or not connected with dancing. This is not an interest in performance, but rather in explaining each word in the text.

When it comes to "real" dancing and dance steps, the results are even more disappointing. A search for words linked with the root $\chi 0 \rho$ - for the noun "chorus" and its derivatives yields nothing aside from the scholia discussing the chorus as a speaking (or moving) character which I have just surveyed. If we look for more technical words connected with dancing, we are plunged into purely antiquarian notes. A typical case occurs at Pythian 2, when at line 69 Pindar mentions the "Castoreion." This odd reference prompts a long explanation to clarify that the Castoreion is an armed dance; the commentator discusses its origin and its difference from the pyrrhic dance, quoting many learned sources:

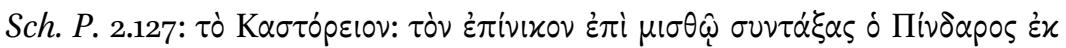

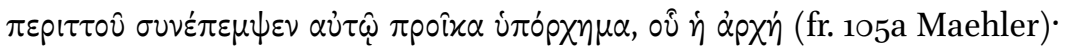

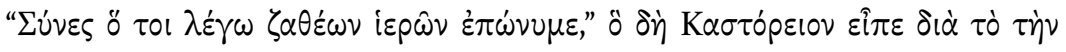

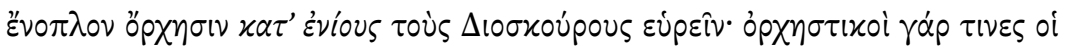

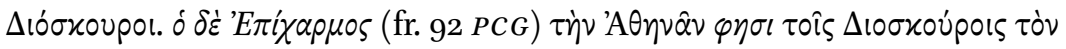

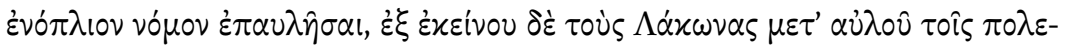

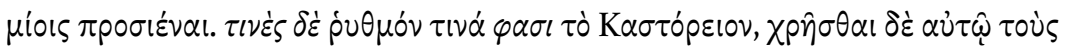

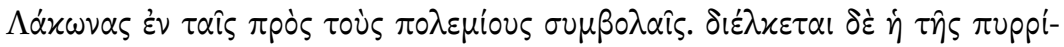

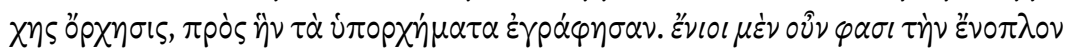

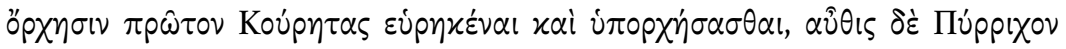

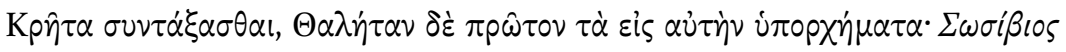

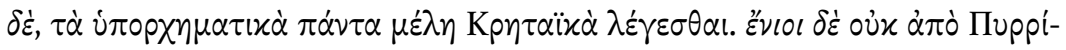

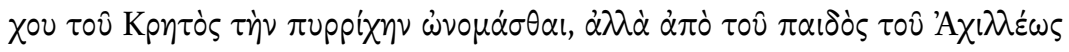

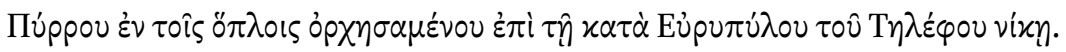

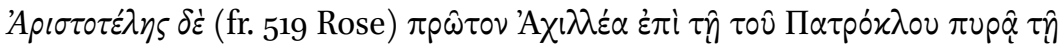

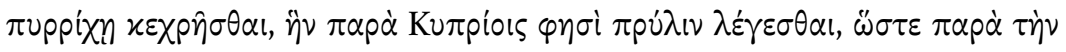

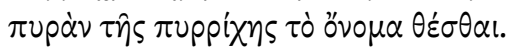


The Castoreion: having composed the epinician for money, in addition Pindar sent him a hyporchema as a gift, whose incipit was: "Understand what I tell you, you whose name means holy temples."48 He called it Castoreion because according to some the Dioscuroi invented the armed dance; for the Dioscuroi were dancers of a sort. And Epicharmus says that Athena played the martial melody on the pipe as an accompaniment for the Dioscuri, and that because of this the Laconians approach the enemies with the accompaniment of the pipe. Some say that the Castoreion is some sort of rhythm and that the Laconians use it when they engage with their enemies. The pyrrhic dance is different [from the Castoreion] and for it [i.e., for the pyrrhic dance] [poets] wrote hyporchemata. Some say that the Curetes first invented the armed dance and danced it, and then the Cretan Pyrrhichus organized it and Thales was the first to compose hyporchemata for it; Sosibius, however, says that all the hyporchematic songs are called Cretan. But some say that the pyrrhic dance is not named after Pyrrhichus the Cretan, but after the son of Achilles, Pyrrhus, who danced in his armor upon his victory over Eurypylus, son of Telephus. Aristotle, on the other hand, says that Achilles first danced the pyrrhic dance on the pyre of Patroclus, which, he says, the Cyprians call "prylis," so that the name "pyrrhic" derives from "pyre."

Again, the learned scholium derives from the necessity of explaining an obscure reference in the text. This is mostly an antiquarian note focusing on the mythical origin of the dance and quoting a lot of learned authorities, but without any description of the steps or what this dance looks like. The interest is broadly historical, not performance-oriented. Otherwise, the explanations are text-derived. For example, there are several scholia discussing the "Archilochus song," which Pindar mentions in the opening of Olympian 9, saying that the hymn is sung at Olympia, has a refrain sung three times, and is celebrated by the

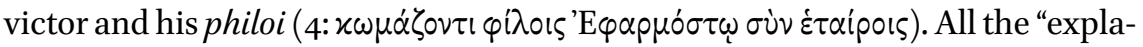
nations" in the preserved scholia simply rephrase what Pindar has already said in these opening lines (Sch. O. 9.1a-k). Or they contain an "educated guess," for example that the song is "triple" (2: $x \alpha \lambda i v i x \circ \varsigma \dot{\delta} \tau p(\pi \lambda \dot{0} 0 \varsigma x \varepsilon \chi \lambda \alpha \delta \dot{\omega} \omega)$ not because it has three refrains but because it is performed once at the time of the victory, then in the gymnasium, and then at home, or because (Aristarchus' opinion) it had three strophes (Sch. O. 9.3a-l). The few other examples discussing choral 
dancing in the scholia are all along these same lines: they try to explain the words used in the text, and never go beyond them. ${ }^{49}$

This result on the chorus' movements in the Pindar scholia parallels the situation concerning the musical element. As noted by Lucia Prauscello, ${ }^{50}$ scholia seem to guess references to musical modes based on ethnic qualifiers. ${ }^{51} \mathrm{In}$ addition, just as with the scholia commenting on choral dance, none of these scholia actually explains what these harmonies are from a musical point of view. ${ }^{52}$

\section{The Chorus Dances ... in Theory}

The conclusions reached on the basis of the Pindar scholia do not, however, mean that in their work ancient critics took no interest at all in choral dancing, music, and more generally the performative aspects of lyric poetry. We simply do not find annotations on these elements in their exegetical and editorial practice, but elsewhere. Didymus, the famous Alexandrian scholar, seems to have taken both music and choral performance into account when discussing the different genres of choral lyric in his lost work on Lyric Poets. We have only some fragments, ${ }^{53}$ and one of them is particularly interesting:

49 See also, e.g., Sch. N. 3.1c. All occurrences of the root $\sigma \tau \rho$ - (which covers $\sigma \tau \rho \dot{\varepsilon} \varphi \varepsilon \varepsilon v, \sigma \tau p \circ \varphi \eta$, $\sigma \tau p \circ \varphi$ ós, etc.) refer to metrical division, so they are not relevant here. The only exception

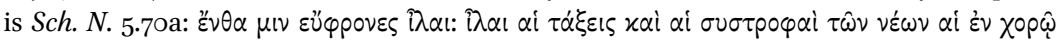

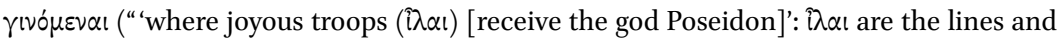
the turns of the youths, those happening in the chorus"). Here too the reference to the movements and turns of the chorus is suggested by the text itself (i $i \alpha \mathrm{\alpha l}$, "troops," often of soldiers). I suspect that the military meaning of $i \lambda \alpha$ ı suggested to the mind of the scholiast the marching movements and the twists of the chorus dancers.

50 Prauscello 2012: 77-82 (esp. 79).

51 Dorian mode (Sch. O. 1.26a, c, g; Sch. O. 3.9a, c, d); Aeolian mode (Sch. O. 1.164b; Sch. P. 2.125c and 128a; Sch. N. 3.136a); Lydian mode (Sch. O. 5.44a, c, g, i; Sch. O. 14.23c; Sch. N. 4.71; Sch. N. 8.24a, b); Locrian mode (Sch. O. 10.17k and 10.18b). Among papyri, POxy. 26.2449 has

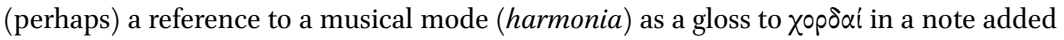
in the lower margin; cf. McNamee 2007:348.

52 My survey also confirms the conclusions reached by Prauscello 2006 about Greek music and Alexandrian commentators. Reacting especially against Thomas Fleming and E. Christian Kopff but also against the Gentili school that claimed that Alexandrian grammarians systematically used musical scores in order to edit lyric poetry, Prauscello has shown that the evidence does not support this claim. See especially Prauscello 2006: 7121. The connection between music and scholarly practice is also very thin in the papyri surveyed by Martinelli 20oga.

They are collected and discussed by Grandolini 1999 . 


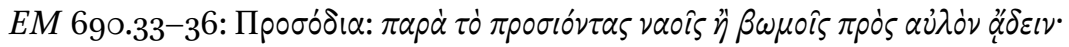

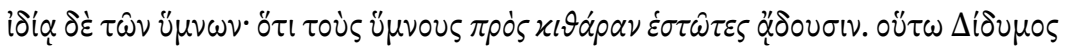
$\dot{\varepsilon} \nu \tau \hat{\omega} \pi \varepsilon p i \lambda \nu \rho i x \hat{\omega} \nu \pi \circ i \eta \tau \hat{\omega} \nu .54$

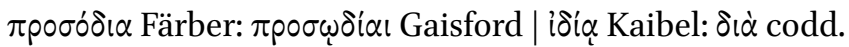

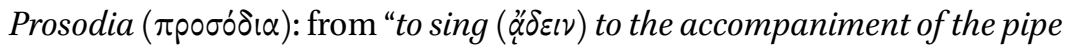

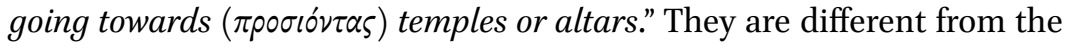
hymns. Because they sing hymns standing in place and to the accompaniment of the kithara. Thus Didymus in On Lyric Poets.

The etymology of the prosodion is connected with the movements of the chorus, which goes towards temples and altars. And prosodia are opposed to hymns exactly because the chorus behaves differently and the musical accompaniment is different. A related passage is found in the so-called Byzantine Capitula:

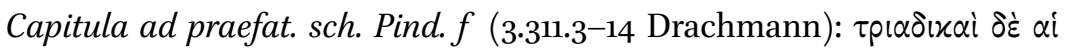

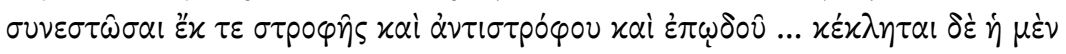

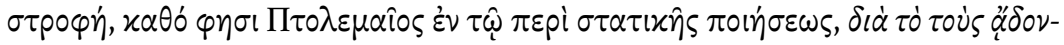

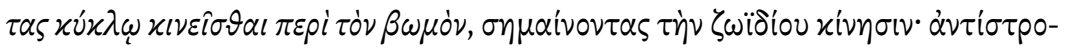

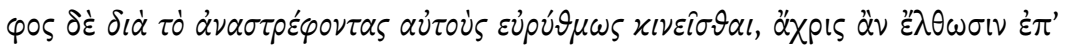

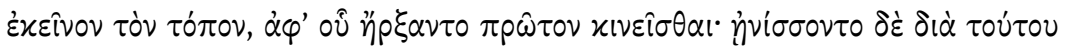

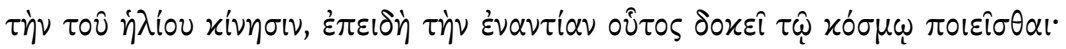

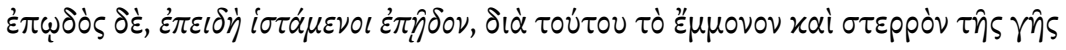
$\pi \alpha \rho เ \tau \tau \hat{\omega} \tau \tau \varsigma$.

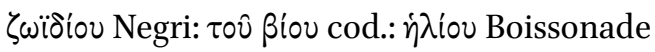

The odes organized in strophe, antistrophe, and epode are triadic ... It is called strophe, as Ptolemaeus says in his On Stationary Poetry, because those who sing move around the altar in a circle, signifying the movement of the zodiac. The antistrophe [is so called] because they move in the opposite direction according to the rhythm until they reach the spot from which they first started moving. With this movement they hinted at the movement of the sun, because this seems to move in the opposite direction 
from the cosmos. The epode [is so called] because they sang it standing still, representing in this way the firm stillness of the earth.

Monica Negri has proven conclusively that this Ptolemy is not Claudius Ptolemaeus but Ptolemy Epithetes, a grammarian contemporary with Aristarchus. ${ }^{55}$ In his treatise entitled On Stationary Poetry he explained the terms strophe, antistrophe, and epode on the basis of choral movements, not very differently from Didymus. The analogy between celestial and choral movements is very well attested in antiquity, both in tragedy ${ }^{56}$ and in other sources which give a cosmological interpretation of the chorus, as in the passage above. ${ }^{57}$ This doctrine, probably derived from Pythagorean sources, ${ }^{58}$ is beyond the scope of this analysis. The note in the Capitula, however, is interesting for our inquiry because it proves that Alexandrian grammarians did take into consideration the chorus' movements and music when defining and framing choral lyric as a genre. As for Ptolemy, the very title of his monograph, On Stationary Poetry

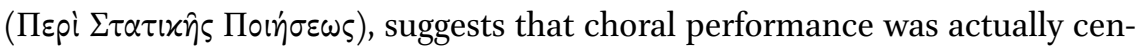
tral when discussing lyric poetry from a theoretical perspective, so that it was at the basis of its technical terminology. Some dramatic scholia also explain the word stasimon with reference to choral movement (or, rather, lack thereof), for example the following: ${ }^{59}$

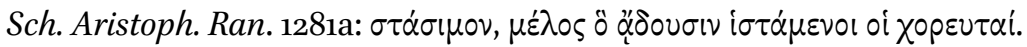

Stasimon, a song which the choreutai sing standing still.

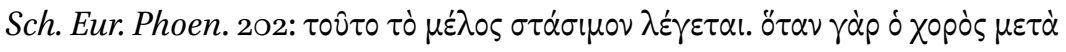

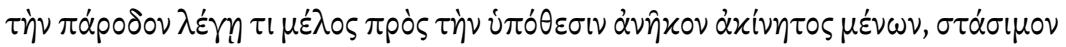

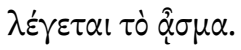

This song is called stasimon. For when after the parodos, the chorus, standing without moving, delivers a song connected to the content of the play, the song is called stasimon.

55 Negri 2001, against Montanari 1988: 107-109.

56 E.g., Eur. El. 464-469, Soph. Ant. 1146-1152. For a survey and discussion of star imagery in tragedy, see Csapo 2008.

57 Cf. Färber 1936:20-22 (who still believed that the theory came from Claudius Ptolemaeus). Many of the scholia discussing the triadic structure of choral dancing are analyzed by Briand 2009.

58 Cf. Negri 2001: 126-127.

59 All these examples are discussed by Negri 2001:135-136; my analysis is very much indebted to hers. 
Interestingly enough, Aristotle gives a different definition of stasimon when he says that it is the part of the chorus' song without anapaests and trochees

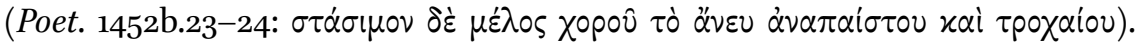
Here Aristotle does not take the movements of the chorus into consideration but only the metrical patterns of the lines. Of course, meter and dancing steps were connected, but this connection is absent in Aristotle's definition. This suggests that the same phenomenon (the choral performance) could be looked at in two very different ways by Greek scholars: it could be considered as a dancing body which physically moved on a floor (so Didymus and Ptolemy Epithetes) or it could be seen in more abstract terms, as a portion of a text, characterized by a specific metrical pattern (so Aristotle). The latter characteristic was of course originally an aural phenomenon connected with performance and with the dancing steps. Yet a metrical pattern was also something which (unlike the dancing) could be reproduced and "seen" in a written text, at least since the time when the Greek alphabet, as well as new writing conventions, allowed scribes to signal long and short syllables more accurately. ${ }^{60}$ Metrical patterns, unlike dancing steps, were the focus of Aristotle when describing the chorus. But this is the point of view of a "reader" rather than a "spectator" of lyric poetry.

\section{Conclusions}

In this article I have tried to show that the question to ask is not if ancient scholars had an interest in performance but rather when and how this interest emerges.

Ancient commentators did take an interest in music and choral dancing at a theoretical level to distinguish between different types of lyric poetry, as Didymus and Ptolemy Epithetes do. In the exegetical practice on specific authors and odes, however, they do not seem to have been interested in the most purely performative aspects of lyric poetry, such as the music and the choral performance. The performance-related references in the scholia originate from the text. These textual references then lead the commentator to guess the chorus' activities or the musical element. Yet these explanations are mostly antiquar-

6o This happened with the adoption of the Ionic alphabet, which differentiated between $\varepsilon$ vs. $\eta$ and 0 vs. $\omega$ and which was introduced in Athens at the end of the fifth century. In fact, such an alphabet may have been widely used even earlier than 403/4O2 BCE and beyond Attica; see D'Angour 1999: 120-123. In addition, Aristotle (Soph. el. 177b4-7) seems to know reading signs $(\pi \alpha \rho \dot{\sigma} \sigma \eta \mu \alpha)$ which made it possible to disambiguate words also in terms of vowel length. 
ian (origin of a dance or of a musical mode) or deduced from clues in the text itself. Nevertheless, even if most often the explanations are text-derived, we cannot exclude the possibility that sometimes grammarians could have used additional evidence to support their analyses. The idea of semi-choruses, for example, suggested by the text of Alcman's partheneion, could have been supported by the historical research of Sosibius, who is in fact also quoted in the scholium on the Castoreion (above, pp. 124-125). Yet the exegetes' interest in the extratextual realities of a lyric passage, sometimes backed up by antiquarian sources, started only from the text itself, when it required some explanation beyond the linguistic one.

These data seem to match what Nünlist has found in his study of performance-related notes in dramatic scholia. ${ }^{61}$ If his analysis gives the impression that there are quite a few notes discussing stage action in dramatic scholia, this is simply because to understand a dramatic plot a reader must visualize what is happening onstage. ${ }^{62}$ In addition, most notes discussing stage action in scholia to Greek drama can be deduced from the text itself, just as with Pindar.

In my view, this "textual" attitude towards performance arose from two different and coexisting factors. On the one hand, the lack of interest in performance is inherited from Aristotle. Just as he defined a stasimon in terms of meter and not of dance, so he famously excluded spectacle, that is, performance, from the technical parts of tragedy:

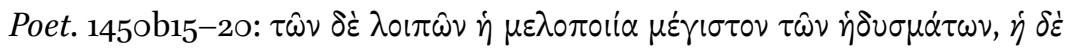

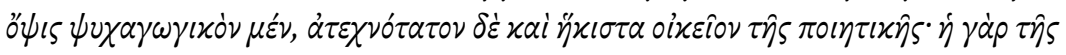

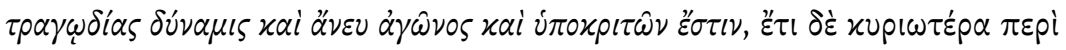

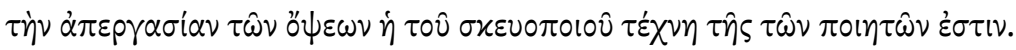

Of the other [parts], song is the greatest element to spice up poetry. Spectacle is something that appeals to our imagination but lacks any technical expertise and is the least peculiar to poetic art. For the potential of tragedy exists even without performance and actors; moreover, to produce spectacles the technical expertise of the one who makes stage equipment is more important than the technical expertise of the poets.

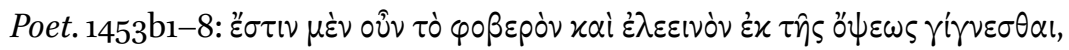

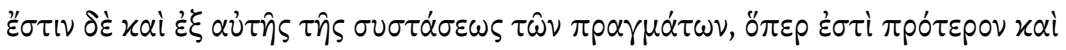

$61 \quad$ Nünlist 2009: $33^{8-365}$.

62 As Nünlist 2009: 365 , himself recognizes: "most of the relevant notes primarily serve the needs of a reading audience." 


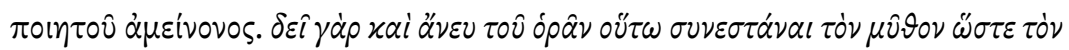

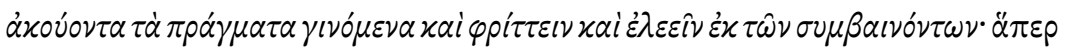

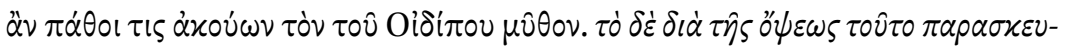

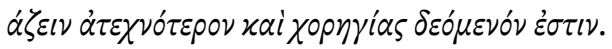

What causes fear and pity can happen through spectacle, but also from the structure of the incidents itself, which is superior and [the mark] of a better poet. For the plot should be put together in a way that, even without watching, one who hears the events that unfold in it will shiver with fear and feel pity at what happens; this is what someone listening to the plot of Oedipus would feel. To obtain this effect through spectacle requires less technical skill and needs abundant means for the production. ${ }^{63}$

If, following Aristotle, performance was not considered really part of dramatic poetry, at least from a technical point of view, then later "literary critics" might have concluded that the performative aspects of archaic and classical poetry did not belong to the exegetical practice. This attitude explains what we read in the lyric and dramatic scholia. Scholars knew that these genres, especially lyric poetry, had music and dancing. They therefore had to deal with these elements, but took them into account only in theoretical discussions, when "framing" the different types of lyric poetry. However, music and choral performance did not impact their exegetical and editorial practice. What really mattered to them was the text, and the text itself gave all the answers they needed.

In addition, there was the lesson of the Alexandrians and in particular of Aristarchus, who inaugurated the practice of clarifying an author from the author himself. ${ }^{64}$ Even if we might not like the many text-derived explanations in the Pindar scholia, for the ancients this was sound methodology because it meant to "clarify Pindar from Pindar," following the teaching of the most renowned of the grammarians, Aristarchus.

63 On the problematic status of the chorus and choral performance in the Poetics, see Halliwell 1986: 238-252; cf. also Peponi 2013c: 23-26; Weiss 2018: 3-6.

64 The maxim "to clarify Homer from Homer," often ascribed to Aristarchus, is not by him but rather is used by Porphyry to define his own methodology in the Homeric Questions (QH

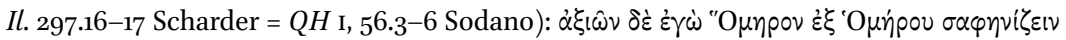

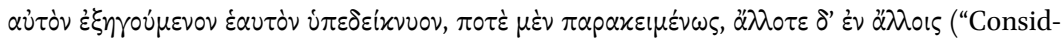
ering it right to explain Homer from Homer, I have shown that Homer interprets himself sometimes in passages which are nearby, sometimes in other [more remote] passages"). Cf. Pfeiffer 1968: 226-227, and Porter 1992: 73-80. Aristarchus did, however, consistently apply the principle of clarifying Homer from Homer in his philological activity; see Schironi 2018. 
Finally, the ancients looked at genres according to the speakers. The distinction among dramatic, narrative, and "mixed" genres is familiar to modern readers above all from Plato and Aristotle; yet, as we have seen, it is also reflected in some ancient editions attested in papyrus fragments, which signal the speakers within the poem: they are the Homeric heroes as well as "the poet," i.e., Homer. The previous analysis suggests that Pindar's epinicians, too, belonged to the "mixed" genre, because the poet behaves like Homer, intruding in the text with his own voice as well as introducing characters who speak in their own personae: the chorus and the victor. Alcman's partheneion, in contrast, might have been considered "dramatic," with the girls of Agido and those of Hagesichora as the only speakers, as $P$. Louvre suggests. ${ }^{65}$

In the Homeric poems and Pindar's victory odes, both belonging to the "mixed" type, the poets were speakers just like their characters or, in the case of Pindar's odes, the "real" performers in the chorus. Yet this dialogue among characters (whether it was purely dramatic or mixed) was firmly set on the page. And one could simply explain these texts with the text itself. Clarifying an author from the author himself was a very good principle when applied by Aristarchus to Homer, as it avoided allegorical readings extraneous to the text. However, because of the influence of Aristotle and Aristarchus and because both Homer and choral poetry were considered "dialogues among speakers," this principle was unfortunately applied to Pindar and Alcman, who might instead have benefited from a look beyond the text.

65 A similar reconstruction was suggested by Rutherford 2001: 101, for some lyric genres, when he hypothesized that while the dithyramb belonged to the diegetic (or narrative) genre, the hyporchema belonged to the mimetic (or dramatic) genre, and the paean to the mixed genre. 